\title{
Fitur Ekstraksi Berbasis Discrete Wavelet Transform Untuk Pengenalan Karakter Pada Plat Nomor Kendaraan
}

\author{
Feature Extraction Based On Discrete Wavelet Transform For Character Recognition On License \\ Plate Number
}

\author{
Edi Sugiarto ${ }^{1}$, Amiq Fahmi² \\ ${ }^{1}$ Program Studi Teknik Informatika, Fakultas Ilmu Komputer, Universitas Dian Nuswantoro \\ ${ }^{2}$ Program Studi Manajemen Informatika, Fakultas Ilmu Komputer, Universitas Dian Nuswantoro \\ Jl. Nakula I No 5-11 Semarang 50131, Telp : (024) 3517361, Fax : (024) 3520165 \\ E-mail : ${ }^{1}$ edi.sugiarto@dsn.dinus.ac.id, ${ }^{2}$ amiq.fahmi@dsn.dinus.ac.id
}

\begin{abstract}
Abstrak
Fitur ekstraksi merupakan langkah penting dalam pengenalan karakter. Hasil dari keseluruhan sistem pengenalan karakter sangat tergantung pada keberhasilanya suatu sistem mengekstrak fitur-fitur tiap objek yang akan dikenali. Wavelet Transform dapat digunakan untuk melakukan fitur ekstraksi karena dapat melakukan dekomposisi ruang vektor kedalam sekumpulan ruang vektor bersarang dengan resolusi yang berbeda sehingga memungkinkan dilakukan analisis terhadap fungsi baik pada domain waktu maupun domain frekuensi.Dalam penelitian ini wavelet transform digunakan untuk melakukan ekstraksi fitur citra huruf plat nomor kendaraan, untuk mendapatkan fitur dari citra tersebut dilakukan dekomposisi dengan wavelet hingga level 4. Pengujian dilakukan menggunakan 140 citra dimana tiap citra yang digunakan menggunakan ukuran resolusi 128x128 piksel. Dari hasil pengujian maka dapat dibuktikan bahwa level dekomposisi terbaik untuk ekstraksi fitur dengan metode wavelet transform adalah level 3 dengan panjang vektor fitur 24 dan dengan tingkat akurasi hingga $97.1 \%$.
\end{abstract}

Kata Kunci : Discrete Wavelet Transform, Fitur Ekstraksi,Support Vector Machine, plat nomor.

\begin{abstract}
Feature extraction is an important step in character recognition. The results of the whole character recognition system depend on the success of a system to extract features of each object to be recognized. Wavelet Transform can be used to perform the extraction feature because it can decompose vector space into a set of nested vector space with different resolution, so that can be analyzed to function both at time domain and frequency domain. In this research wavelet transform is used to perform feature extraction of letters Vehicle number plate, to get the feature of the image is done decomposition with wavelet up to level 4 . The test is done using 140 images where each image used using the size of resolution $128 \times 128$ pixels. From the test result, it can be proven that the best decomposition level for feature extraction with wavelet transform method is level 3 with 24 feature vector length and with an accuracy of $97.1 \%$.
\end{abstract}

Keywords: Discrete Wavelet Transform, Feature Extraction, Support Vector Machine, license plate.

\section{PENDAHULUAN}

Intelligent Transportation System (ITS) merupakan suatu sistem berbasis teknologi yang dibagi menjadi Intelligent Infrastructure System dan Intelligent Vehicle System [1][2]. Vehicle Identification sebagai bagian dari Intelligent Vehicle System memainkan peran penting karena setiap plat nomor yang melekat pada setiap kendaraan digunakan untuk tujuan identifikasi secara resmi [3]. Terdapat 
beberapa alasan kenapa diperlukan identifikasi sebuah kendaraan, yakni untuk tujuan seperti : penegakan hukum, kontrol lalu lintas, tol elektronik, parker, serta akses ke daerah terlarang [3]. Sebagai bagian dari ITS, teknologi pengenalan karakter plat nomor kendaraan merupakan teknik penting yang memiliki tiga area yakni deteksi lokasi plat nomor, Segmentasi karakter Plat Nomor, dan Pengenalan Karakter Plat Nomor [2]. Fitur ekstraksi memainkan peranan penting dalam keberhasilan proses pengenalan karakter pada plat nomor kendaraan.

Fitur ekstraksi merupakan langkah penting dalam pengenalan karakter. Hasil dari keseluruhan sistem sangat tergantung dengan keberhasilanya sistem mengekstrak fitur-fitur tiap objek yang akan dikenali. sehingga diperlukan teknik untuk men-seleksi dan meng-ekstrak fitur-fitur yang relevan untuk meningkatkan performa sistem pengenalan karakter [3][4]. Penelitian terkait dengan pengenalan plat nomor kendaraan telah dilakukan oleh Edi Sugiarto [2]. Tujuan dalam penelitian tersebut adalah mengukur akurasi klasifikasi menggunakan metode Support Vector Machine. Penelitian dilakukan melalui tiga tahapan pertama adalah tahap segmentasi, kedua tahap fitur ekstraksi, dan ketiga tahap klasifikasi. Dalam penelitian tersebut menyimpulkan bahwa dengan kemampuan yang baik untuk meng ekstrak fitur tiap kelas dapat meningkatkan akurasi proses pengenalan karakter [2].

Wavelet Transform dapat digunakan untuk melakukan fitur ekstraksi karena dapat melakukan dekomposisi ruang vektor kedalam sekumpulan ruang vektor bersarang dengan resolusi yang berbeda sehingga memungkinkan dilakukan analisis terhadap fungsi baik pada domain waktu maupun domain frekuensi [5]. Wavelet transform telah sukses diaplikasikan pada beberapa bidang seperti pengolahan citra, analisa numerik, analisis signal, komputer grafik dll [5]. Penelitian berkaitan dengan wavelet transform untuk fitur ekstraksi diuraikan sebagai berikut: Rong-Tsai Lee [6] menggunakan Discrete Periodic Wavelet Transform untuk mendeteksi lokasi plat nomor kendaraan, Nanik[5] menggunakan wavelet transform untuk mengekstrasi fitur citra tekstur dalam sistem temu kembali. Geraldo [7] menggunakan wavelet transform untuk mereduksi fitur pada klasifikasi dokumen.

Dari beberapa penelitian berkaitan dengan penerapan wavelet transform yang telah dilakukan, maka pada penelitian ini discrete wavelet transform dipilih untuk diterapkan pada tahap fitur ekstraksi dalam pengenalan karakter plat nomor kendaraan.

\subsection{Penelitian Terkait}

\section{METODE PENELITIAN}

Penelitian terkait dengan penggunakan metode wavelet transform pernah dilakukan oleh RongTsai Lee dan King-Chu Hung [6]. Dalam penelitianya mengenai deteksi plat nomor kendaraan, metodenya dilakukan dalam beberapa tahapan: license plate training dan license plate recognition. Tahap license plate training dilakukan dengan: memasukkan citra inputan, melakukan preprocessing dengan meresize ukuran menjadi 32x64, kemudian mereduksi fitur citra teresebut menjadi 7 kolom, kemudian melakukan training dengan neural network.

Pada tahap license plate recognition dilakukan dengan: memasukkan citra yang akan dikenali, melakukan preprocessing, melakukan scanning window dengan ukuran 32x64, kemudian menggunakan neural network untuk melakukan pengenalan. Dari percobaan yang dilakukan dibuktikan bahwa akurasi pengenalan posisi plat nomor mencapa 94.7\%. perbedaan dengan penelitian ini adalah letak penggunaan metode discrete wavelet transform, dalam penelitian tsb metode wavelet transform diterapkan pada proses fitur ekstraksi untuk menentukan lokasi plat nomor, sedangkan pada penelitian ini diterapkan pada proses fitur ekstraksi untuk mengenali karakter pada plat nomor kendaraan. 
Penelitian terkait dengan pengenalan karakter juga pernah dilakukan oleh Edi Sugiarto [2]. Penelitian dilakukan dengan tujuan mengukur akurasi metode SVM dengan parameter sigma (ó) dan penalty (C) terbaik, penelitian dilakukan dalam dua tahap yakni tahap training dan tahap recognition. proses training dilakukan dalam tiga tahap yakni : preprocessing, fiture extraction, dan trainning menggunakan SVM. Tahap fitur ekstraksi dilakukan dengan memetakan suatu citra dalam matrik 5x5 kemudian dengan menghitung tiap piksel pada tiap area, sehingga tiap citra huruf memiliki vektor dengan dimensi 25x1 sebagai fitur hasil ekstraksinya. proses recognition dilakukan dalam tahapan : preprocessing, segmentation, fiture extraction dan classification. Dalam penelitian tersebut disimpulkan bahwa dengan parameter siqma (ó) $=0.8$ dan pinalti $(C)=15$ memiliki akurasi terbaik hingga 91\% namun masih memiliki kekurangan dalam fitur ekstraksi, karena dengan mapping image masih memiliki beberapa kemiripan untuk beberapa fitur sehingga dengan menggunakan metode untuk fitur ekstraksi yang tepat akurasi pengenalan karakter dapat ditingkatkan. Sehingga dalam penelitian ini diusulkan metode discrete wavelet transform untuk metode pada fitur ekstraksi tersebut.

\subsection{Discrete Wavelet Transform}

Transformasi wavelet merupakan perbaikan dari transformasi fourier. Pada transformasi fourier hanya dapat menentukan frekuensi yang muncul pada suatu sinyal namun tidak dapat menentukan kapan frekuensi tersebut muncul. Transformasi wavelet selain mampu memberikan informasi frekuensi yang muncul, juga dapat memberikan informasi tentang skala atau durasi atau waktu [8]. Representasi wavelet pada citra adalah menggunakan transformasi wavelet diskrit 2 dimensi (2D) [5]. proses transformasinya dilakukan dengan langkah berikut : citra semula ditransformasi menjadi 4 sub-image baru untuk menggantikanya. Tiap sub-image berukuran 1/4 kali dari citra asli. 3 sub-image pada posisi kanan atas, bawah kiri dan bawah kanan akan terlihat versi kasar karena berisi frekuensi tinggi dari citra asli. Sedangkan 1 sub-image di bagian kiri atas akan terlihat halus karena berisi komponen frekuensi rendah. Dari 1 sub-image dengan frekuensi rendah tersebut dapat dibagi menjad 4 sub-image baru, proses demikian dilakukan seterusnya dengan level transformasi yang diinginkan [8]. Pada citra 2D proses transformasi dilakukan pada baris terlebih dahulu, kemudian dilanjutkan dengan transformasi pada kolom.

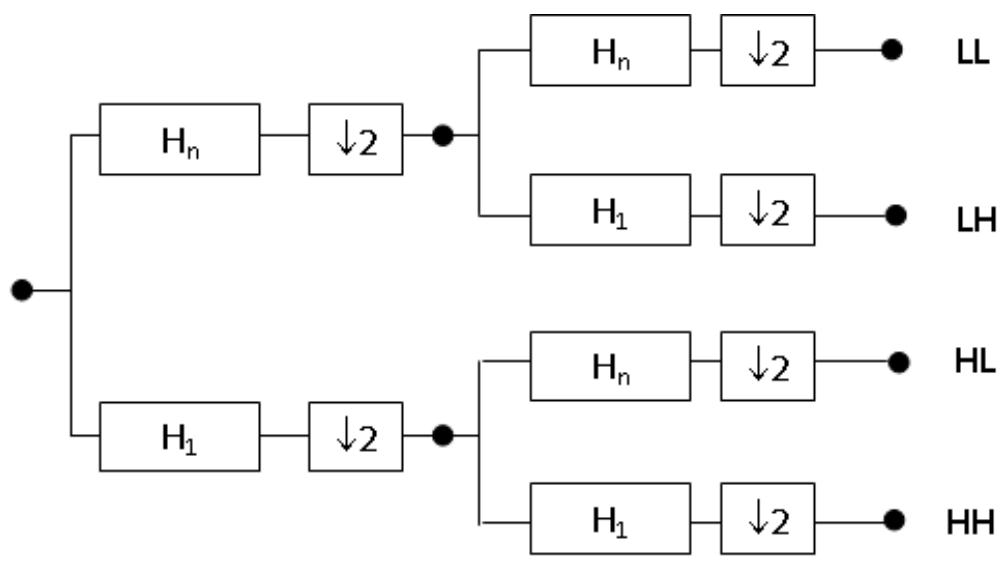

Gambar 1. Transformasi Wavelet 2D

Hasil transformasi wavelet 2D sering dibuat dalam bentuk skema berikut: 


\begin{tabular}{|c|c|}
\hline $\mathrm{LL}$ & $\mathrm{HL}$ \\
\hline $\mathrm{LH}$ & $\mathrm{HH}$ \\
\hline
\end{tabular}$=$\begin{tabular}{|c|c|}
\hline Aproximation & Vertical Details \\
\hline Horizontal Details & Diagonal Details \\
\hline
\end{tabular}

Gambar 2. Transformasi Wavelet 2D CA, CV, CH, dan CD berturut-turut menyatakan komponen Aproksimasi, Vertikal, Horizontal, dan Diagonal.

\subsection{Fitur Ekstraksi Dengan Discrete Wavelet Transform}

Proses fitur ekstraksi dilakukan melalui beberapa tahap, tahap pertama yakni preprocessing, pada tahap preprocessing data gambar dilakukan untuk meningkatkan kualitas gambar, tahap kedua yakni fitur ekstraksi, fitur ekstraksi dilakukan untuk mendapatkan ciri dari suatu gambar serta mereduksi dimensi citra dari dimensi yang tinggi ke dimensi yang lebih rendah. Pada tahap fitur ekstraksi digunakan metode discrete wavelet transform. Proses ini digambarkan dalam diagram berikut:

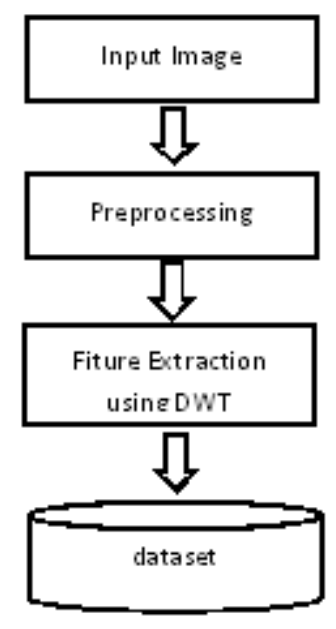

Gambar 3. Proses Ekstraksi Fitur.

\subsubsection{Preprocessing}

Proses pre processing image merupakan tahap untuk menentukan kulitas citra yang akan di ekstraksi. Pada tahapan pro processing dilakukan transformasi citra dari citra RGB ke dalam bentuk grayscale kemudian dilakukan proses skeletonisasi citra.
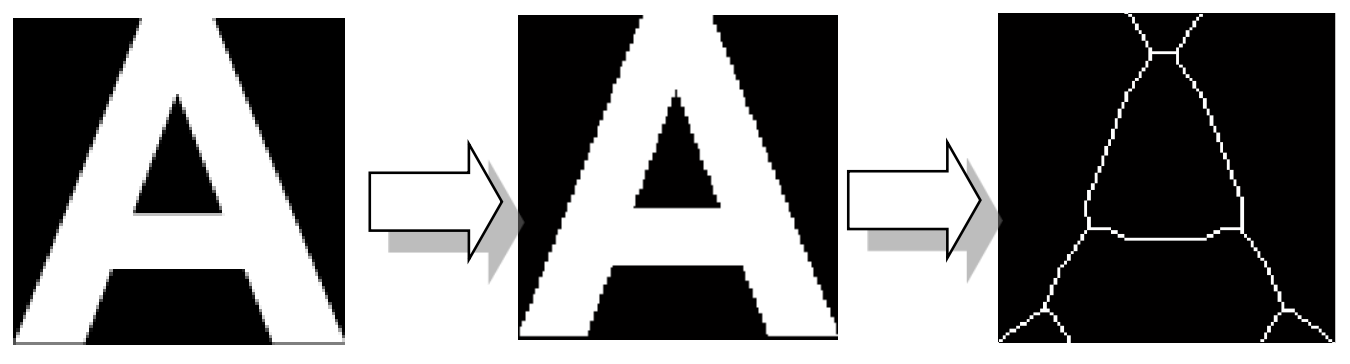

Gambar 4. Proses tansformasi citra 


\subsubsection{Ekstraksi Fitur}

Setelah tahap preprocessing maka selanjutnya dilakukan proses fitur ekstraksi untuk memunculkan ciri serta mereduksi dimensi citra dari dimensi yang tinggi ke dimensi yang lebih rendah, proses fitur ekstraksi dilakukan menggunakan metode discrete wavelet transform. Langkah yang dilakukan pada tahap ini yakni melakukan dekomposisi citra hingga level 4. Pada setiap level dekomposisi akan menghasilkan empat sub citra yaitu : aproksimasi (cA), informasi frekwensi tinggi arah horisontal $(\mathrm{cH})$, informasi frekwensi tinggi arah vertikal $(\mathrm{cV})$, dan informasi frekwensi tinggi arah diagonal $(\mathrm{cD})$.

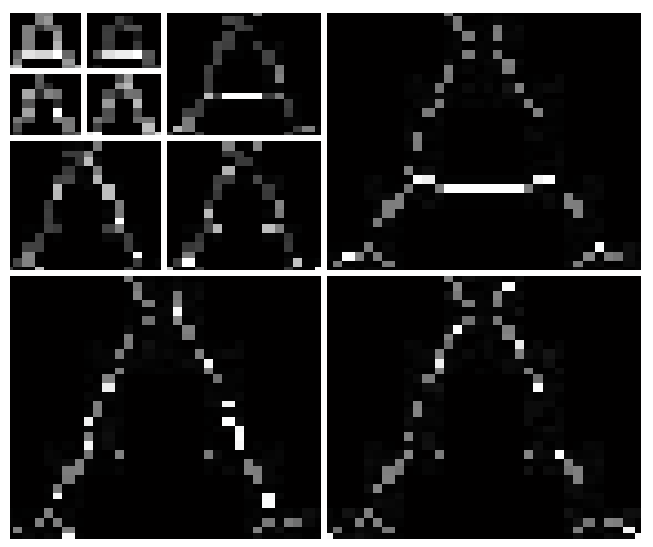

Gambar 5. Skema dekomposisi wavelet 3 level

Kemudian akan dilakukan perhitungan energi dan standar deviasi pada tiap sub citra. Sehingga pada level 1 akan mendapatkan 8 vektor fitur yang terdiri dari 4 vektor fitur energi dan 4 vektor fitur standar deviasi. Maka jika dekomposisi dilakukan hingga level 4 akan mendapatkan 32 vektor fitur. Energi dan standar deviasi dihitung dari persaman berikut:

$\mathrm{E}=\frac{1}{M x N} \sum_{i=1}^{M} \sum_{j=1}^{N}\left|x_{i j}\right|$

$\operatorname{Std}=\left[\frac{1}{M x N} \sum_{i=1}^{M} \sum_{j=1}^{N}\left(x_{i j}-\mu_{i j}\right)^{2}\right]^{1 / 2}$

Dimana MxN merupakan ukuran sub citra hasil dekomposisi. $\mathrm{X}_{\mathrm{ij}}$ merupakan koefisien wavelet dan $\mu_{\mathrm{ij}}$ merupakan rata-rata koefisien wavelet.

Selanjutnya setelah proses fitur ekstraksi dilakukan akan terbentuk dataset berupa fitur-fitur dari setiap citra yang selanjutnya dari dataset fitur tersebut dapat dilakukan proses training dan klasifikasi untuk mengetahui tingkat kurasi klasifikasi dari fitur yang dihasilkan.dalam penelitian ini klasifikasi dilakukan menggunakan metode Support Vector Machine dengan pendekatan One Againts All dan kernel RBF. 


\section{HASIL DAN PEMBAHASAN}

Ujicoba dilakukan dengan menggunaan citra berupa huruf sebanyak 108 citra yang mewakili 3 sample tiap huruf yaitu A-Z dan 0-9, data citra ini digunakan untuk training. Kemudian menggunakan 140 citra untuk testing. Tiap citra yang digunakan menggunakan ukuran resolusi 128x128 piksel.
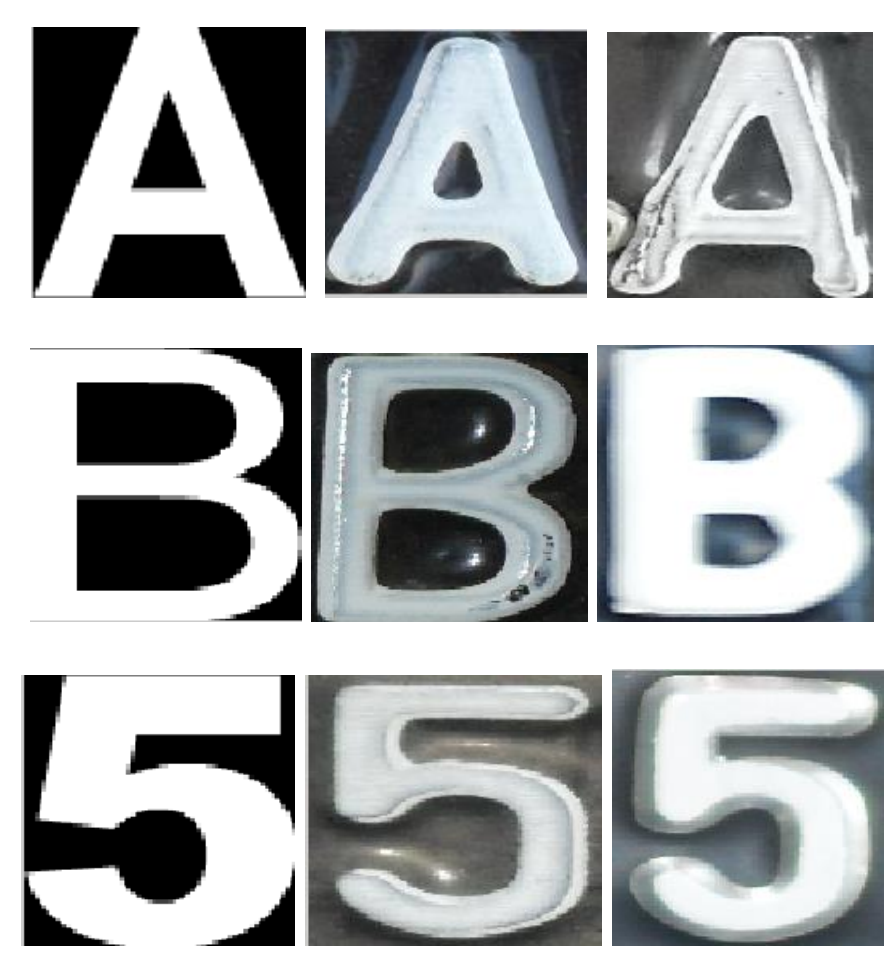

Gambar 6. Citra huruf dan angka plat nomor yang digunakan untuk training

Untuk mendapatkan fitur dari citra tersebut dilakukan dekomposisi dengan wavelet. Pada dekomposisi level 1 didapat 8 vektor fitur yang terdiri dari 4 vektor fitur energi dan 4 vektor fitur deviasi. Langkah dekomposisi dilakukan hingga level 4 dimana hingga level 4 akan didapatkan 32 vektor fitur. Panjang vektor fitur dan level dekomposisi dapat dilihat pada tabel berikut:

Tabel 1. Panjang vektor fitur dan level dekomposisi

\begin{tabular}{|l|l|}
\hline Level Dekomposisi & Panjang Vektor Fitur \\
\hline Level 1 & 8 \\
\hline Level 2 & 16 \\
\hline Level 3 & 24 \\
\hline Level 4 & 32 \\
\hline
\end{tabular}


Pengujian akurasi dilakukan pada tiap level dekomposisi untuk mengetahui tingkat akurasi terbaik dari fitur yang diperoleh dengan metode wavelet. Pengujian dilakukan dengan pertamakali melakukan training dari fitur pada tiap level. Training dan klasifikasi dilakukan dengan menggunakan metode SVM berbasis pendekatan one against all (OAA). Kernel yang digunakan pada SVM yakni Radial Basis Function (RBF) dengan parameter deviasi (ó) $=0.1$ dan parameter Pinalti $(\mathrm{C})=10$. Metode pengukuran akurasi menggunakan Confusion Matrix yang membagi ke dalam kelas : data positif (true positif/TP; false positive/FP) dan data negative (true negative /TN; false negative/FN). Dengan perhitungan akurasi sbb:

Akurasi $=(\mathrm{TP}+\mathrm{TN}) /(\mathrm{TP}+\mathrm{TN}+\mathrm{FP}+\mathrm{FN})$

Dari pengujian yang telah dilakukan maka dapat dilihat tingkat akurasi klasifikasi dari tiap level dekomposisi sbb:

Tabel 2 Tabel pengukuran tingkat akurasi

\begin{tabular}{|l|c|c|c|c|c|}
\hline $\begin{array}{c}\text { Level } \\
\text { Demposisi }\end{array}$ & $\begin{array}{c}\text { True } \\
\text { Positive } \\
(T P)\end{array}$ & $\begin{array}{c}\text { False } \\
\text { Positive } \\
(F P)\end{array}$ & $\begin{array}{c}\text { True } \\
\text { Negative } \\
(\text { TN })\end{array}$ & $\begin{array}{c}\text { False } \\
\text { Negative } \\
(F N)\end{array}$ & $\begin{array}{c}\text { Over All } \\
\text { Accuracy } \\
(\text { AC) }\end{array}$ \\
\hline Level 1 & 57 & 83 & 0 & 0 & 0.407 \\
\hline Level 2 & 120 & 20 & 0 & 0 & 0.857 \\
\hline Level 3 & 136 & 4 & 0 & 0 & 0.971 \\
\hline Level 4 & 134 & 6 & 0 & 0 & 0.957 \\
\hline
\end{tabular}

Dari tabel pengukuran diatas maka dapat dibuktikan bahwa level dekomposisi terbaik untuk ekstraksi fitur dengan metode wavelet adalah level 3 dengan tingkat akurasi 97.1\%.

\section{KESIMPULAN}

Berdasarkan hasil penelitian yang telah dilakukan dengan menerapkan metode discrete wavelet transform pada proses fitur ekstraksi untuk tiap citra huruf maupun angka pada plat nomor kendaraan maka didapatkan vektor fitur dengan panjang yang beragam sesuai dengan level dekomposisi. Fiturfitur yang diperoleh didasarkan pada energy dan standar deviasi dari koefisien wavelet hasil dekomposisi. Pengukuran akurasi dilakukan menggunakan metode SVM untuk klasifikasi dengan metode pengukuran menggunakan confusion matrix. Dari hasil eksperimen yang telah dilakukan dengan menggunakan sebanyak 140 citra huruf maupun angka dari plat nomor kendaraan maka dapat dibuktikan bahwa hasil akurasi terbaik adalah fitur dengan panjang 24 hasil dari dekomposisi hingga level 3 dengan tingkat akurasi hingga 97.1\%. secara umum vektor fitur yang dihasilkan dari transformasi wavelet ini cukup mewakili karakteristik dari sebuah citra huruf maupun angka dari plat nomor kendaraan.

\section{SARAN}

Penelitian ini dilakukan untuk menguji metode discrete wavelet transform pada proses fitur ekstraksi, fitur dari hasil ekstraksi tersebut kemudian diklasifikasi menggunakan metode Support 
Vector Machine sehingga didapatkan tingkat akurasi. Namun pada penelitian ini pengujian masih sebatas tingkat akurasi huruf per hururf dari plat nomor, sehingga pada penelitian selanjutnya dengan metode ini dapat dilakukan pengujian untuk mengukur tingkat akurasi pengenalan karakter dengan mengenali citra huruf dalam satu plat nomor.

\section{DAFTAR PUSTAKA}

[1] Weijuan Wen, Xiangli Huang, and Pengju Zhang (2009), "The Vehicle License Plat Location Method Baseon Wavelet Transform", 2009 International Joint Conference on Computational Sciences and Optimization, Communication University of China.

[2] Sugiarto, Edi. (2013). "Pengenalan Karakter Pada Plat Nomor Kendaraan Berbasis Support Vector Machine". Techno. Com, 12(1), 1-15.

[3] Swati Jagtap (2015), "Analysis of Feature Extraction Techniques for Vehicle Number Plate Detection", International Journal of Computer Science and Information Technologies Vol. 6 (6), 5342-5346.

[4] Youjie Qiu, et all (2009), "License Plate Extraction Based on Vertical Edge Detection an Mathematical Morphology", IEEE 978-1-4244-4507-3.

[5] Nanik Suciati (2013),'Ekstraksi Fitur Berbasis Wavelet Pada Sistem Temu Kembali Citra Tekstur", jurnal SCAN VOL. VII NOMOR 2 ISSN: 1978-0087.

[6] Rong-Tsai Lee (2012), "Real-Time Vehicle License Plate Recognition Based On 1-D Discrete Periodic Wavelet Transform", International Symposium on Computer, Consumer, and Control, 978-0-7695-4655$1 / 12$ IEEE.

[7] Geraldo et all (2008), "Using Wavelet to Classify Documents", IEEE/WIC/ACM International Conference on Web Intelligence and Intelligent Agent Technologi, 978-0-7695-3496-1/08.

[8] Darma Putra (2010), "Pengolahan Citra Digital", Penerbit Andi, Yogyakarta. 